\title{
Gymnodimine A and 13-desMethyl Spirolide C Alter Intracellular Calcium Levels via Acetylcholine Receptors
}

\author{
Joyce A. Nieva, Bernd Krock $\mathbb{D}^{\mathbb{D}}$, Urban Tillmann ${ }^{\mathbb{D}}$, Jan Tebben ${ }^{\mathbb{D}}$, Christian Zurhelle ${ }^{\mathbb{D}}$ \\ and Ulf Bickmeyer *(D)
}

Alfred Wegener Institute, Helmholtz Center for Polar and Marine Research, D-27570 Bremerhaven, Germany; joyce.nieva@awi.de (J.A.N.); Bernd.Krock@awi.de (B.K.); urban.tillmann@awi.de (U.T.); jan.tebben@awi.de (J.T.); christian.zurhelle@awi.de (C.Z.)

* Correspondence: ulf.bickmeyer@awi.de; Tel.: +49-471-4831-2028

Received: 13 November 2020; Accepted: 26 November 2020; Published: 27 November 2020

check for updates

\begin{abstract}
Gymnodimines and spirolides are cyclic imine phycotoxins and known antagonists of nicotinic acetylcholine receptors (nAChRs). We investigated the effect of gymnodimine A (GYM A) and 13-desmethyl spirolide C (SPX 1) from Alexandrium ostenfeldii on rat pheochromocytoma (PC12) cells by monitoring intracellular calcium levels $\left([\mathrm{Ca}]_{\mathrm{i}}\right)$. Using whole cells, the presence of $0.5 \mu \mathrm{M}$ of GYM A or SPX 1 induced an increase in [Ca $]_{i}$ mediated by acetylcholine receptors (AChRs) and inhibited further activation of AChRs by acetylcholine (ACh). To differentiate the effects of GYM A or SPX 1, the toxins were applied to cells with pharmacologically isolated nAChRs and muscarinic AChRs (mAChRs) as mediated by the addition of atropine and tubocurarine, respectively. GYM A and SPX 1 activated $n A C h R s$ and inhibited the further activation of nAChRs by ACh, indicating that both toxins mimicked the activity of ACh. Regarding $\mathrm{mAChRs}$, a differential response was observed between the two toxins. Only GYM A activated mAChRs, resulting in elevated $[\mathrm{Ca}]_{\mathrm{i}}$, but both toxins prevented a subsequent activation by ACh. The absence of the triketal ring system in GYM A may provide the basis for a selective activation of mAChRs. GYM A and SPX 1 induced no changes in [Ca $]_{i}$ when $\mathrm{nAChRs}$ and $\mathrm{mAChRs}$ were inhibited simultaneously, indicating that both toxins target AChRs.
\end{abstract}

Keywords: cyclic imine; nicotinic, muscarinic, and acetylcholine receptors; calcium signaling; Alexandrium ostenfeldii

Key Contribution: Gymnodimine A and 13-desmethyl spirolide C show a similar effect on nicotinic acetylcholine receptors and a differential response to muscarinic acetylcholine receptors.

\section{Introduction}

The frequency and widespread occurrence of marine biotoxins associated with microalgae has increased over the years [1]. Among the emerging classes of lipophilic marine toxins are the macrocyclic imine compounds such as prorocentrolides, spiro-prorocentrimine, gymnodimines, spirolides, pinnatoxins, and portimine [2].

Spirolides, one of the classes of cyclic imine, are produced by Alexandrium ostenfeldii [3]. To this day, they have not been found in any other microalgal species. Gymnodimines, on the other hand, have only been recently reported to co-occur with spirolides in at least a number of Alexandrium ostenfeldii strains [4-8] and were initially identified in Karenia selliformis [9]. The presence of structurally related gymnodimines and spirolides in a single microalgal species suggests that both toxins share a common biosynthetic pathway. In addition to the cyclic imine moiety, the butenolide side chain is identical for gymnodimines and spirolides, indicating a common function in both toxin types [10]. 
Functional bioassays on gymnodimine A (GYM A, Figure 1A) and 13-desmethyl spirolide C (SPX 1, Figure 1B) revealed a similar bioactivity. Since both induce rapid neurotoxic symptoms in mice after intraperitoneal injection or oral administration, they are called "fast-acting toxins" [11]. Moreover, results from in vivo assays showed that the time for symptoms to manifest shortened and the onset of death accelerated when cholinergic or acetylcholinesterase inhibitors were simultaneously administered. These observations prompted studies to determine the mechanism by which the toxins affect acetylcholine receptors (AChRs) [12,13]. Electrophysiological measurements using clonal cells demonstrated that while GYM A as well as SPX 1 broadly targets muscular and neuronal nicotinic AChRs (nAChRs) [14-17], only GYM A showed a reversible effect [14]. These studies used both homomeric and heteromeric subtypes such as $\alpha 7, \alpha 1_{2} \beta 1 \gamma \delta, \alpha 7-5 \mathrm{HT}_{3}, \alpha 3 \beta 2$, and $\alpha 4 \beta 2 \mathrm{nAChRs}$. The effect of SPX 1 on muscarinic AChRs (mAChRs) was determined using a human neuroblastoma cell model. It showed the antagonistic effect of the toxin that resulted in a reduced function and decreased specificity of $m A C h R s$ [18]. However, recent studies contradicted this model and showed that neither SPX $1[15,17]$ nor GYM A [17] strongly interact with mAChR subtypes $\mathrm{M}_{1}-\mathrm{M}_{5}$.
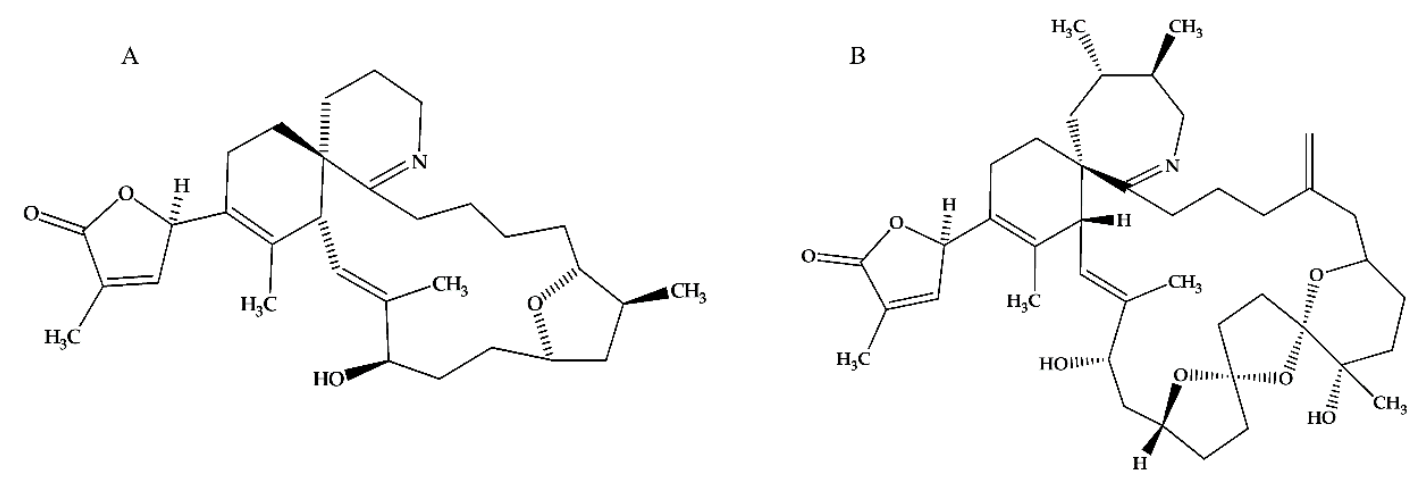

Figure 1. Chemical structure of Gymnodimine A (GYM A) (A) and 13-desmethyl spirolide C (SPX 1) (B) [16].

Only a few bioactivity studies other than the mouse bioassay [11] and in vitro inhibition assays [12-18] have been performed on gymnodimines and spirolides. Electrophysiological measurements were limited to a specific receptor, which was overexpressed [19]. Considering that GYM A and SPX 1 have shown anticholinergic effects on nAChRs in recombinant cells [12-18], it is important to determine the effects on cellular signaling.

In neuroendocrine cells such as rat pheochromocytoma (PC 12) cells, many different types of receptors and ion channels are simultaneously present [20,21]. Voltage-gated calcium (Ca) channels and AChRs are known to permeate calcium ions $\left(\mathrm{Ca}^{2+}\right)$ into the cell when the channels are opened as a result of depolarization or binding of acetylcholine (ACh), respectively. Voltage-gated Ca channels are selective gates that regulate the majority of the $\mathrm{Ca}^{2+}$ influx into the cell [22], while nAChRs are non-selective cation channels that are permeable not only to $\mathrm{Ca}^{2+}$ but also to other cations [23]. AChRs can be classified into nicotinic and muscarinic AChRs. While nAChRs function as ionotropic receptors inducing as a fast response in the cell [24], $\mathrm{mAChRs}$ are coupled to G-proteins that use the transmitted signal to activate a cascade of reactions and produce a secondary messenger. Compared to nAChRs, $\mathrm{mAChRs} \mathrm{provide} \mathrm{an} \mathrm{indirect} \mathrm{response} \mathrm{to} \mathrm{a} \mathrm{series} \mathrm{of} \mathrm{reactions} \mathrm{[25].}$

In this study, we investigated the effects of GYM A and SPX 1 on the intracellular $\mathrm{Ca}^{2+}$ $\left([\mathrm{Ca}]_{\mathrm{i}}\right)$ alterations mediated by ion channels and receptors. We chose PC12 cells in order to be able to investigate the effects of toxins on more than one type of receptor and many different ion channels [20]. We specifically aimed to determine the influence of GYM A and SPX 1 on voltage-operated plasma-membrane Ca channels and nicotinic and muscarinic AChRs of PC 12 cells under physiological conditions. Since PC12 cells contain the nAChR subtypes $\alpha 3, \alpha 5, \beta 2-\beta 4$ [26], as well as atypical $\mathrm{mAChR}$ subtypes [27], our approach is more general than previously published works [14-18]. 


\section{Results}

\subsection{Depolarization of $\mathrm{Ca}$ Channels Using $\mathrm{K}^{+}$}

To account for the possibility of the toxins inhibiting voltage-dependent calcium channels, we investigated their influence on depolarization-induced $[\mathrm{Ca}]_{\mathrm{i}}$ changes (Figure 2). This was done to avoid misinterpretation of toxin induced calcium channel inhibition with effects on AChRs. In the controls, an elevation of $[\mathrm{Ca}]_{i}$, induced by high concentrations of $\mathrm{K}^{+}$was associated with a change in fluorescence emission intensity of the Flou-3 AM dye. Baseline recovery of [Ca $]_{i}$ to the baseline was observed after depolarization (Figure $3 \mathrm{~A}$ ).
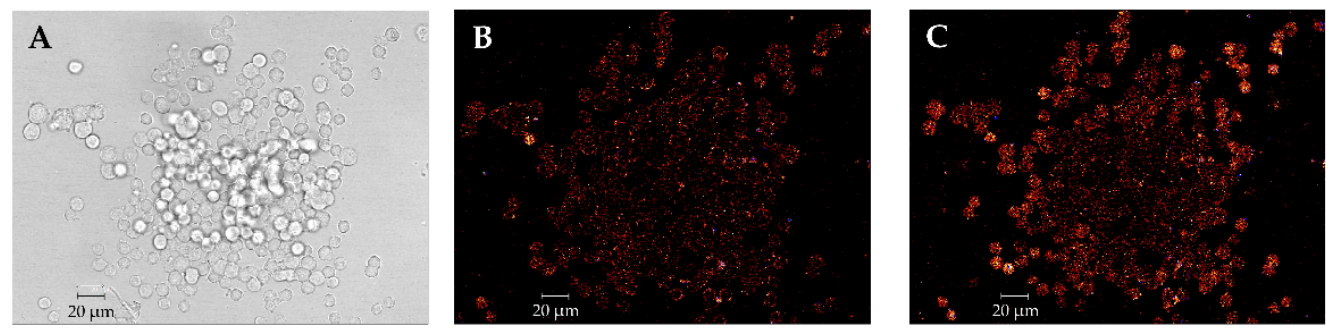

Figure 2. (A) Transmission image of pheochromocytoma (PC12) cells and (B) fluorescence images of flou-3 acetoxymethylester (Flou-3 AM)-stained PC 12 cells before and (C) during depolarization.

Cells incubated with GYM A or SPX $1(0.5 \mu \mathrm{M})$ showed an increase of [Ca $]_{i}$ during depolarization and no calcium channel inhibition (Figure $3 \mathrm{~B}, \mathrm{C}$, respectively). In both treatments, the baseline recovery was delayed (Figure 3B,C) compared to the control (Figure 3A).
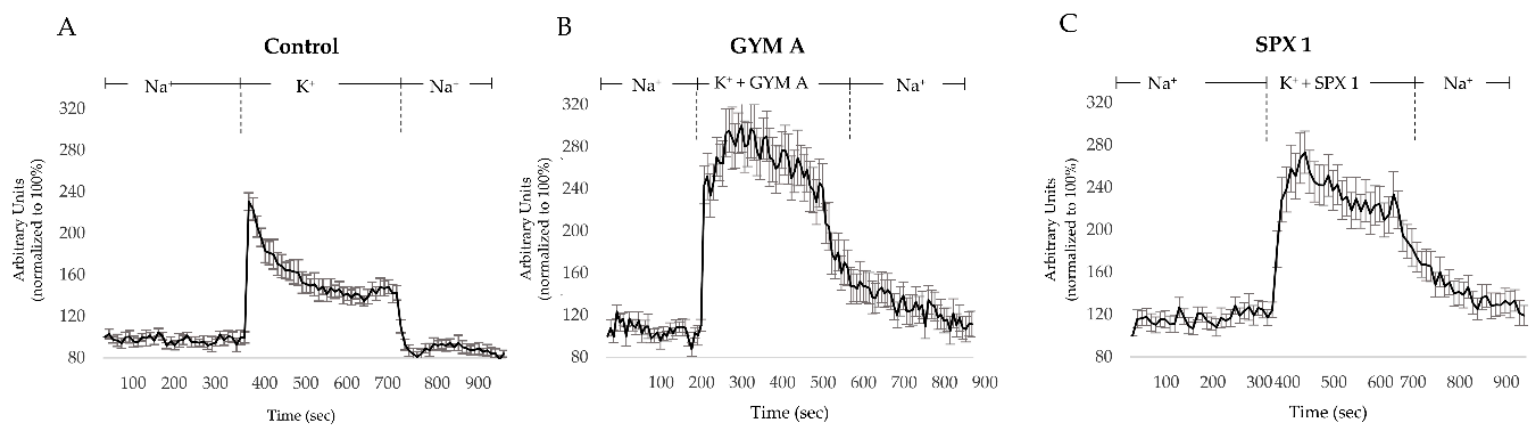

Figure 3. Alterations of fluorescence intensity (FI) induced by $80 \mathrm{mM} \mathrm{K} \mathrm{K}^{+}$. (A) Intracellular calcium levels $\left([\mathrm{Ca}]_{\mathrm{i}}\right)$ changes (shown as arbitrary FI units) induced by activation of voltage-gated calcium channels $\left(\mathrm{K}^{+}\right)$under control conditions and (B) in cells treated with $0.5 \mu \mathrm{M} \mathrm{GYM} \mathrm{A} \mathrm{or} \mathrm{(C)} 0.5 \mu \mathrm{M} \mathrm{SPX}$ 1. $n=10$.

\section{2. $[\mathrm{Ca}]_{i}$ Changes Induced by ACh}

A $[\mathrm{Ca}]_{i}$ elevation, as described by an increase of $[\mathrm{Ca}]_{i}$ from the baseline, was also mediated by ACh (Figure $4 \mathrm{~A}$ ). To reveal the effects of the toxins on $[\mathrm{Ca}]_{i}, \mathrm{GYM}$ A or SPX 1 were applied before ACh (Figure 4B,C).

In cells treated with either $0.5 \mu \mathrm{M}$ (Figure $4 \mathrm{~B}$, in red) or $0.05 \mu \mathrm{M}$ (Figure 4B, in orange) GYM A, an increase of $[\mathrm{Ca}]_{i}$ was observed after the toxins were applied. The successive application of ACh induced no further $[\mathrm{Ca}]_{\mathrm{i}}$ elevation (Figure $4 \mathrm{~B}$, in red and orange). A different pattern was observed for $0.005 \mu \mathrm{M}$ GYM A (Figure 4B, in blue). In this case, no increase in [Ca $]_{i}$ was observed after the addition of GYM A but instead after the ACh was applied.

The application of $0.5 \mu \mathrm{M}$ of SPX 1 also resulted in an increase in $[\mathrm{Ca}]_{\mathrm{i}}$ (Figure $4 \mathrm{C}$, in red). Following the application of $\mathrm{ACh}$, no further $[\mathrm{Ca}]_{\mathrm{i}}$ response was detected. As for the lower concentrations, 
no increase in $[\mathrm{Ca}]_{\mathrm{i}}$ was observed after the addition of 0.05 and $0.005 \mu \mathrm{M}$ SPX 1 . When ACh was subsequently applied, a $[\mathrm{Ca}]_{i}$ elevation was observed (Figure $4 \mathrm{C}$, in orange and blue).

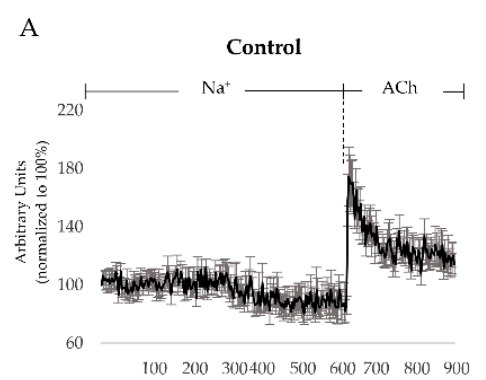

Time (sec)

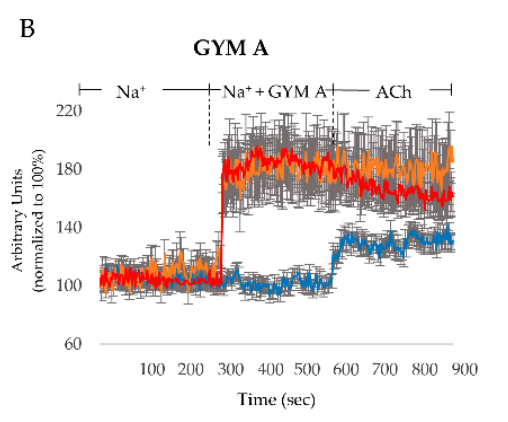

- with $0.5 \mu \mathrm{M}$ toxin

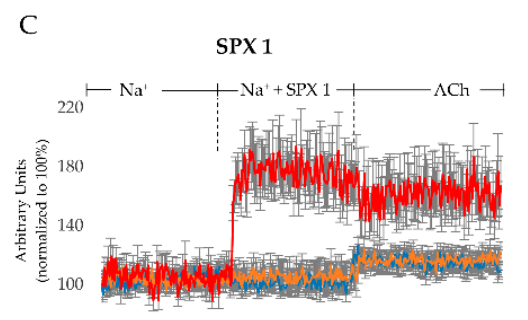

$100 \quad 200 \quad 300400 \quad 500 \quad 600 \quad 700 \quad 800 \quad 900$

Time (sec)

Figure 4. $[\mathrm{Ca}]_{i}$ changes induced by ACh, GYM A, and SPX 1. (A) $[\mathrm{Ca}]_{i}$ level changes induced by activation of AChRs under control conditions; (B) in cells treated with GYM A in the concentrations $0.005 \mu \mathrm{M}$ (blue), $0.05 \mu \mathrm{M}$ (orange), and $0.5 \mu \mathrm{M}$ (red); and (C) SPX 1 in the concentrations $0.005 \mu \mathrm{M}$ (blue), $0.05 \mu \mathrm{M}$ (orange), and $0.5 \mu \mathrm{M}$ (red). $n=10$.

To differentiate the effects of both toxins on AChRs present in the cells, we pharmacologically isolated the effect of the toxins on $\mathrm{nAChRs}$ by using the $\mathrm{mAChR}$-blocker atropine (Figure $5 \mathrm{~A}-\mathrm{C}$ ). Under control conditions, a response in $[\mathrm{Ca}]_{\mathrm{i}}$ was observed upon the addition of ACh to nAChRs (Figure $5 \mathrm{~A}$ ). In cells treated with atropine and $0.5 \mu \mathrm{M}$ GYM A (Figure 5B, in red) and $0.05 \mu \mathrm{M}$ GYM A (Figure 5B, in orange), a $[\mathrm{Ca}]_{i}$ response was observed. The subsequent application of $\mathrm{ACh}$ induced no further increase in $[\mathrm{Ca}]_{i}$. For $0.005 \mu \mathrm{M}$ GYM A (Figure 5B, in blue), only a slight increase of FI ( 10\%) was observed when the toxin was added along with atropine. Upon application of ACh (Figure 5B, in blue), $[\mathrm{Ca}]_{\mathrm{i}}$ increased further ( $30 \%$ FI increase). When SPX 1 (0.5, 0.05, and 0.005; Figure 5C, in red, orange, and blue, respectively) was applied together with atropine, an increase in $[\mathrm{Ca}]_{i}$ was observed at all three concentrations. Upon application of $\mathrm{ACh}$, no additional $[\mathrm{Ca}]_{\mathrm{i}}$ response was observed in 0.5 and $0.05 \mu \mathrm{M}$ SPX 1-treated cells. However, in cells treated with $0.005 \mu \mathrm{M}$ SPX 1 (Figure 5C, in blue), an increase in $[\mathrm{Ca}]_{\mathrm{i}}$ by ACh was evident.

The effect of the toxins on mAChRs was investigated by adding nAChR-blocker tubocurarine. Under control conditions, a response in $[\mathrm{Ca}]_{\mathrm{i}}$ was observed upon the addition of $\mathrm{ACh}$ to $\mathrm{mAChRs}$ (Figure 5D). In cells treated with $0.5,0.05$, and $0.005 \mu \mathrm{M} \mathrm{GYM} \mathrm{A,} \mathrm{a} \mathrm{dose-dependent} \mathrm{increase} \mathrm{of}[\mathrm{Ca}]_{i}$ was observed (Figure 5E, in red, orange, and blue, respectively). At the highest concentration used in this study $(0.5 \mu \mathrm{M})$, no further $[\mathrm{Ca}]_{\mathrm{i}}$ response was observed after additional ACh was applied (Figure $5 \mathrm{E}$, in red). For the two lower concentrations, 0.05 and $0.005 \mu \mathrm{M}$, an increase of $[\mathrm{Ca}]_{\mathrm{i}}(\sim 20 \% \mathrm{FI}$ increase) was observed (Figure 5E, in orange and blue, respectively). A different response was observed when SPX 1 was applied on mAChRs. A decrease of $[\mathrm{Ca}]_{\mathrm{i}}(\sim 5-10 \% \mathrm{FI})$ was measured in cells treated with SPX 1 (Figure 5F, in red, orange, and blue, respectively). In cells treated with 0.5 and $0.05 \mu \mathrm{M}$ SPX 1 (Figure $5 \mathrm{~F}$, in red and orange, respectively), the addition of ACh resulted in no further change in $[\mathrm{Ca}]_{\mathrm{i}}$. In cells treated with $0.005 \mu \mathrm{M}$ SPX 1 (Figure $5 \mathrm{~F}$, in blue), however, the addition of ACh induced a [Ca $]_{i}$ elevation $(\sim+40 \% \mathrm{FI})$. 


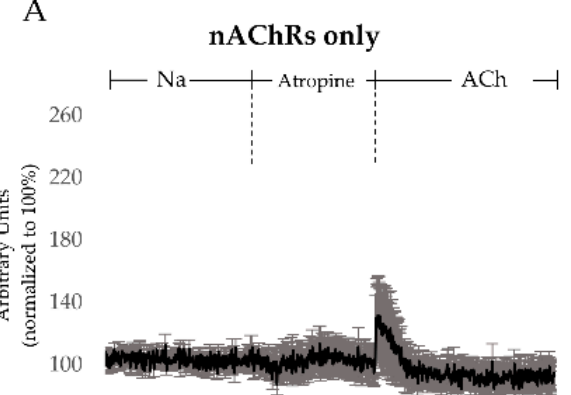

60

$\begin{array}{llllllll}100 & 200 & 300 & 400 & 500 & 600 & 700 & 800\end{array}$ Time (sec)

D

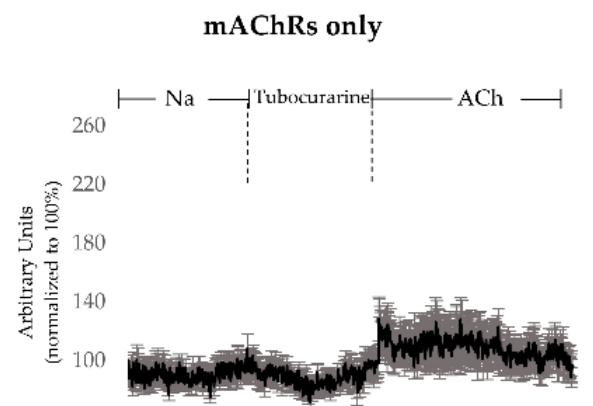

$\begin{array}{llllllll}100 & 200 & 300 & 400 & 500 & 600 & 700 & 800\end{array}$
B

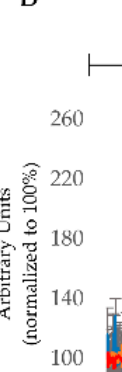$$
60
$$

60

E

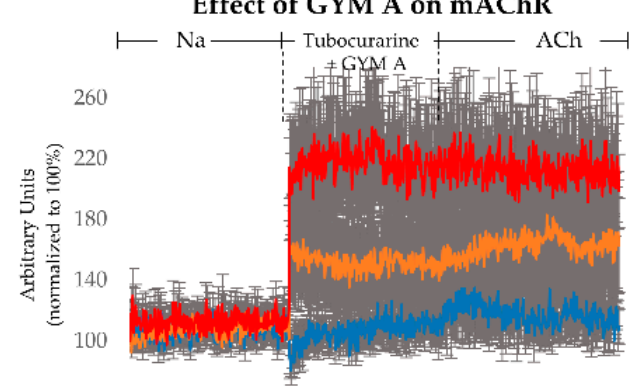

$\begin{array}{llllllll}100 & 200 & 300 & 400 & 500 & 600 & 700 & 800\end{array}$ Time (sec)
C

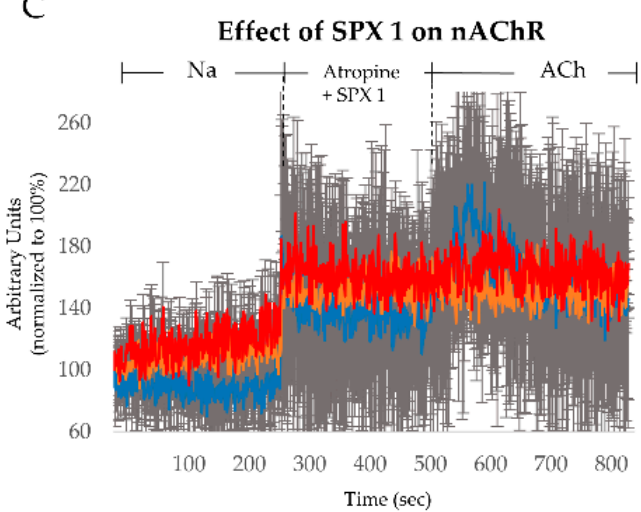

F

\section{Effect of SPX 1 on mAChR}

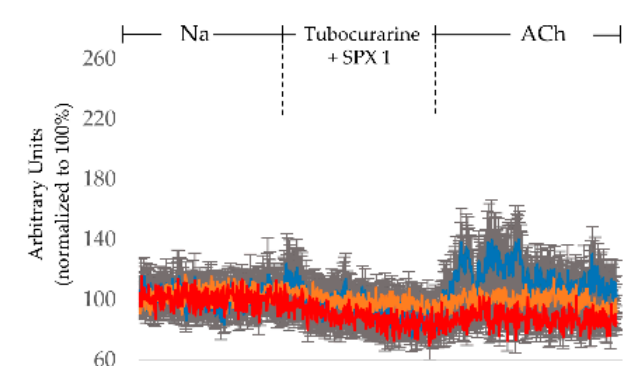

$\begin{array}{llllllll}100 & 200 & 300 & 400 & 500 & 600 & 700 & 800\end{array}$

— with $0.5 \mu \mathrm{M}$ toxin $\quad$ - with $0.05 \mu \mathrm{M}$ toxin $\quad$ with $0.005 \mu \mathrm{M}$ toxin

Figure 5. $[\mathrm{Ca}]_{\mathrm{i}}$ changes induced by acetylcholine (ACh), GYM A, and SPX 1 through pharmacologically isolated nicotinic acetylcholine receptors (nAChRs) or muscarinic AChRs (mAChRs). (A) [Ca $]_{i}$ level changes in cells pretreated with only mAChR-blocker atropine and (B) atropine with GYM A in the concentrations $0.005 \mu \mathrm{M}$ (blue), $0.05 \mu \mathrm{M}$ (orange), and $0.5 \mu \mathrm{M}$ (red) followed by the application of ACh. (C) [Ca] $]_{i}$ level changes in cells pretreated with mAChR-blocker atropine and SPX 1 in the concentrations $0.005 \mu \mathrm{M}$ (blue), $0.05 \mu \mathrm{M}$ (orange), and $0.5 \mu \mathrm{M}$ (red) followed by the application of ACh. (D) [Ca $]_{i}$ level changes in cells pretreated with only nAChR-blocker tubocurarine and (E) tubocurarine with GYM A in the concentrations $0.005 \mu \mathrm{M}$ (blue), $0.05 \mu \mathrm{M}$ (orange), and $0.5 \mu \mathrm{M}$ (red) followed by the application of ACh. (F) [Ca $]_{i}$ level changes in cells pretreated with nAChR-blocker tubocurarine and SPX 1 A in the concentrations $0.005 \mu \mathrm{M}$ (blue), $0.05 \mu \mathrm{M}$ (orange), and $0.5 \mu \mathrm{M}$ (red), followed by the application of ACh. $n=10$. 
In order to rule out effects of the toxins on cellular targets involved in $[\mathrm{Ca}]_{\mathrm{i}}$ signaling other than AChRs, either GYM A or SPX $1(0.5 \mu \mathrm{M})$ was applied to the cells while simultaneously inhibiting nAChRs and mAChRs. In both treatments, no obvious change in $[\mathrm{Ca}]_{i}$ was observed. In addition, no $[\mathrm{Ca}]_{\mathrm{i}}$ response was observed after ACh addition (Figure 6A,B).
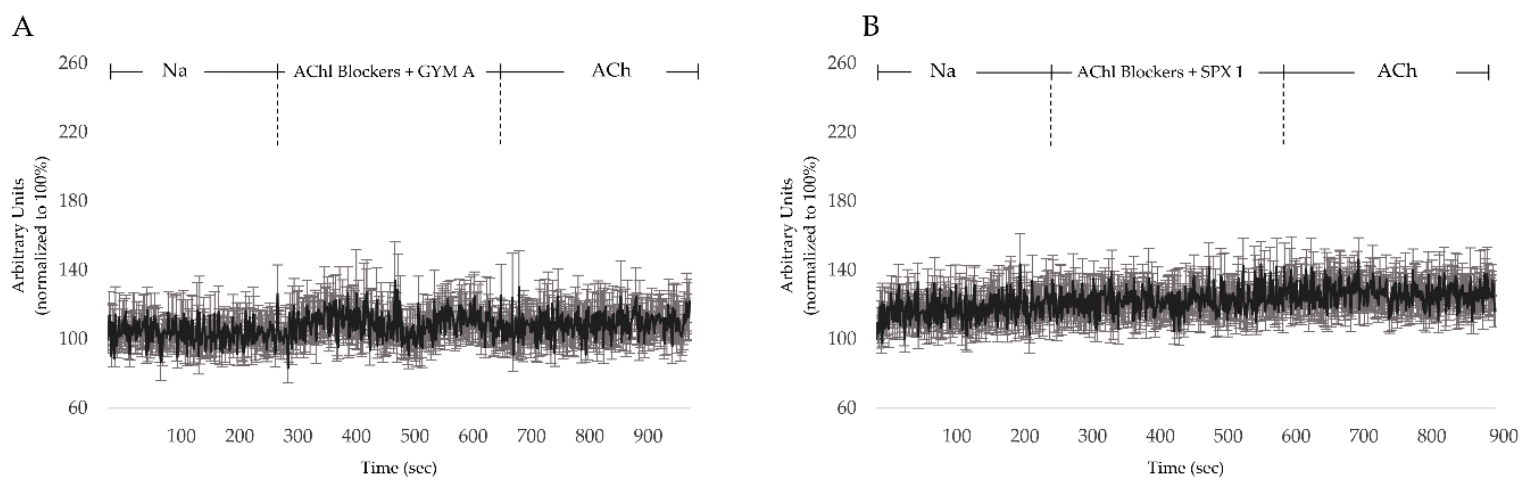

Figure 6. (A) $[\mathrm{Ca}]_{\mathrm{i}}$ level changes in cells pretreated with $\mathrm{mAChR}$-blocker atropine and nAChR-blocker tubocurarine with $0.5 \mu \mathrm{M}$ GYM A and (B) SPX 1. $n=10$.

\section{Discussion}

\subsection{GYM A and SPX 1 Do not Inhibit the Influx of [Ca $]_{i}$ through Voltage-Gated Ca Channels}

First, we excluded the influence of voltage-gated Ca channels on toxin-induced [Ca $]_{i}$ changes. During depolarization, voltage-gated Ca channels mediate the influx of $\mathrm{Ca}^{2+}$ into the cell. Free $\mathrm{Ca}^{2+}$ is removed from the cytosol by uptake into the endoplasmic reticulum and mitochondria and by extrusion mechanisms such as calcium pumps and ion exchangers [28,29]. [Ca $]_{i}$ measurements during depolarization in controls as well as in GYM A- and SPX 1-exposed cells indicate that the toxins do not reduce the influx of $[\mathrm{Ca}]_{i}$ through voltage-gated Ca channels. The gradual decrease in $[\mathrm{Ca}]_{i}$ following depolarization in GYM A- and SPX 1-treated cells (Figure 3B,C, respectively) indicates either an inhibition of transport proteins (e.g., $\mathrm{Ca}^{2+}$ ATPases) that remove $\mathrm{Ca}^{2+}$ from the cell or that the influx of $\mathrm{Ca}^{2+}$ into the cell is mediated by other means [28]. Since AChRs depolarize the cellular membrane and permeate $\mathrm{Ca}^{2+}$ into the cells [23], and GYM A and SPX 1 bind to those receptors, AChRs were chosen as targets for further experiments.

\subsection{GYM A and SPX 1 Alter $[\mathrm{Ca}]_{i}$}

The binding of an agonist such as ACh to AChRs initiate the influx of $\mathrm{Ca}^{2+}$ into the cell. GYM A or SPX 1 tested here had the same effect: the application of $0.05,0.5 \mu \mathrm{M}$ GYM A, and $0.5 \mu \mathrm{M} \mathrm{SPX}$ 1 induced $[\mathrm{Ca}]_{i}$ elevations (Figure $4 \mathrm{~B}$, in red and orange and Figure $4 \mathrm{C}$, in red). The activation of AChRs by either GYM A or SPX 1, particularly at the concentration of $0.5 \mu \mathrm{M}$, may be the reason why a slow and gradual decrease in $[\mathrm{Ca}]_{i}$ was observed in the $\mathrm{K}^{+}$-depolarized cells (Figure $3 \mathrm{~B}, \mathrm{C}$ ). The response observed in $[\mathrm{Ca}]_{\mathrm{i}}$ infers that toxins mimic $\mathrm{ACh}$ and thereby initiate the influx of $\mathrm{Ca}^{2+}$ into the cell. The resulting AChR-toxin complex further inhibits a subsequent activation of AChRs by $\mathrm{ACh}$ (Figure $4 \mathrm{~B}$, in red and orange and Figure $4 \mathrm{C}$, in red). Both toxins activated $\mathrm{AChRs}$ at varying concentrations, with GYM A acting as a more potent activator than SPX 1. Compared to GYM A (at $0.05 \mu \mathrm{M}$, Figure $4 \mathrm{~B}$, in orange), SPX 1 of a higher concentration (at $0.5 \mu \mathrm{M}$, Figure $4 \mathrm{C}$ in red) was needed to induce comparable $\mathrm{Ca}^{2+}$ influx into the cell. At the lowest concentrations $(0.005 \mu \mathrm{M})$ of both toxins, no activation of AChRs was measurable.

\subsection{GYM A and SPX 1 Show a Similar Effect on $n A C h R s$ and a Differential Response to $m A C h R s$}

The difference in response in $[\mathrm{Ca}]_{i}$ between the atropine-treated cells (Figure $5 \mathrm{~A}$ ) and atropine-toxin-treated cells indicate an interaction of GYM A (Figure 5B) and SPX 1 (Figure 5C) 
with nAChRs. Both toxins activate nAChRs, induce entry of $\mathrm{Ca}^{2+}$ into the cells, and block the binding of ACh to nAChRs. At low concentrations $(0.005 \mu \mathrm{M})$, activation of $\mathrm{nAChRs}$ appears in SPX 1(Figure 5C, in blue) but not in GYM A-treated cells (Figure 5B, in blue), demonstrating dose-dependent differences. For both toxins, low concentrations did not inhibit the activation of nAChRs by ACh, resulting in an increase in $[\mathrm{Ca}]_{i}$. Our results support previous studies that showed SPX to have a higher efficacy for nAChRs than GYM A (2-15 fold difference) $[16,17]$.

The contrasting response between cells treated only with tubocurarine and cells that were additionally treated with GYM A or SPX 1 suggests that toxins may have also interacted with mAChRs. GYM A activates $\mathrm{mAChRs}$ dose-dependently. ACh only activates mAChRs at low concentrations of GYM A $(0.005 \mu \mathrm{M})$ (Figure 5E, in blue) where an inhibition of a constitutive activity of receptors may have happened. For SPX 1, a decrease in $[\mathrm{Ca}]_{i}$ was observed that could have been caused by an inhibition of a constitutive activity of $\mathrm{mAChRs}$ [30]. Following the observed decrease in [Ca] $]_{i}$ upon addition of SPX 1, high and moderate concentrations of the toxin inhibit the subsequent activation of mAChRs by ACh (Figure 5F, in red and orange). A low concentration of SPX 1, on the other hand, had no effect (Figure 5F, in blue). GYM A [17] and SPX 1 [15,17] have previously been described to have a low ability to interact with $\mathrm{mAChRs,}$ with the latter having a lower affinity [17]. Here, we show a differential effect of GYM A and SPX 1 on mAChRs.

\subsection{GYM A and SPX Alter [Ca $]_{i}$ through $n A C h R s$ and $m A C h R s$}

At a concentration of $0.5 \mu \mathrm{M}, \mathrm{GYM} A$ and SPX 1 activate $\mathrm{nAChR}$ (GYM A also activates mAChRs) and inhibit the response to ACh. [Ca] $]_{i}$ was not affected by GYM A and SPX $1(0.5 \mu \mathrm{M})$ when both AChR subtypes were blocked simultaneously by atropine and tubocurarine (Figure 6A,B). This shows that $\mathrm{nAChRs}$ and mAChRs must be the primary targets of GYM A and SPX 1 related to [Ca] $]_{i}$ signaling.

Previous studies have demonstrated that both GYM A and SPX 1 acted as antagonists to nAChRs [14-18], while neither interacted strongly with mAChRs [15,17]. Here, we show that GYM A and SPX 1 activate $\mathrm{nAChR}$ at $0.5 \mu \mathrm{M}$ and dose-dependently interact with a successive ACh stimulation. We show that GYM A additionally activates mAChRs at $0.5 \mu \mathrm{M}$ demonstrating that mAChRs are also a target of GYM A. This may be due to different receptor subtypes present in PC12 cells (nAChR subtypes $\alpha 3, \alpha 5, \beta 2-\beta 4$ [26], and atypical mAChR subtypes [27]) compared to subtypes used in studies published previously (nAChR subtypes $\alpha 7, \alpha 1_{2} \beta 1 \gamma \delta, \alpha 7-5 \mathrm{HT}_{3}, \alpha 3 \beta 2$ and $\alpha 4 \beta 2$, and $\mathrm{M}_{1}-\mathrm{M}_{5}$ mAChR subtypes) [14-18]. To investigate structure-activity relationship and to investigate functional measurements due to desensitization mechanism, future electrophysiological studies are required. The potentiation of $\mathrm{nAChRs}$ by atropine is described for specific subunits of the receptor $(\alpha 4 \beta 4)$ [31], which are to our knowledge not present in PC12 cells. A potential interaction site of atropine with nAChRs (inhibition) is the $\alpha 3 \beta 4$ subunit, which is present in PC12 cells [32]. It is therefore possible that in our experiment atropine potentiated the effect of SPX 1 on certain $\mathrm{nAChR}$ subunits and has a small effect during application of a low dose of GYM A. This provides a baseline for future studies.

The response of cells following direct application of higher concentrations of toxins has not been described previously. This study demonstrates GYM A and SPX 1 to dose-dependently interact with AChRs of neuroendocrine PC12 cells. Furthermore, SPX 1 has the capability to inhibit the constitutive activity of mAChRs.

The activation of receptors at high toxin concentrations and inhibition of subsequent activation by ACh at lower concentrations hint at the cooperativity of molecules. In this case, e.g., one molecule binds to one receptor's binding site, preventing further activation by $\mathrm{ACh}$, and when more toxin molecules together bind to more receptor sites, this leads to activation of receptors. The cooperativity can be calculated by the steepness of dose response relationships. This is unfortunately not feasible for our data due to limited amounts of compounds being available and therefore limited dose-response-related data points.

In summary, we show that under physiological conditions, both toxins act as agonists for $\mathrm{nAChRs}$ and that GYM A induces an increase in $[\mathrm{Ca}]_{i}$ through $\mathrm{mAChRs}$. We provide clear evidence that GYM 
A and SPX 1 mimic the action of ACh, preventing further activation of receptors. The macrocyclic nature of GYM A and SPX 1 allows the toxins to conform to the same binding sites of nAChRs with the cyclic imine as the pivot point of the molecule [16]. Absence of a triketal ring system may provide a basis for selective activation of $\mathrm{mAChRs}$ by GYM A as compared to SPX 1 . The difference in activity regarding $\mathrm{nAChRs}$ and $\mathrm{mAChRs}$ observed between the toxins may be due to the subtype selectivity of these receptors. Subtypes of nAChRs, which can be homomeric or heteromeric in form, have different permeabilities to $\mathrm{Ca}^{2+}$ and affinities to ACh [33]. mAChR subtypes couple to different G-protein types, initiating different secondary induction pathways [34]. Structural conformation of the toxins (presence or absence of a triketal ring system) as well as of the AChR subunits plays crucial roles in the selectivity and specificity of toxin-receptor interactions.

\section{Materials and Methods}

\subsection{Extraction and Purification of Gymnodimine A and 13-Desmethyl Spirolide C}

GYM A and SPX 1 were isolated from clonal isolates of Alexandrium ostenfeldii (OKNL 48) collected from Ouwerkerkse Kreek, the Netherlands [5]. The extraction and purification of the toxins was conducted using the procedure described by Zurhelle et al. [9]. In brief, the microalgal culture was treated with acetone ( $7 \%$ final concentration) and the toxins were extracted using conditioned HP-20 (Diaon Supelco, Steinheim, Germany). The resin was eluted with methanol, and the eluate was dried under vacuo before loading into the preparative reversed phase chromatography $(\mathrm{C} 18$, $\left.25 \times 310 \mathrm{~mm}, 5 \mathrm{~mL} \mathrm{~min}^{-1}\right)$. The elution was done with a stepwise gradient from aqueous:acetonitrile $(\mathrm{ACN})($ water/ACN, 80:20 v/v) to $100 \% \mathrm{ACN}$.

\subsection{PC 12 Culture Methods}

Prior to cell cultivation, cover slips were placed into the Petri dishes, coated with $0.5 \mathrm{mg} \mathrm{mL}^{-1}$ collagen A (Biochrom, Berlin, Germany), and dried for $24 \mathrm{~h}$. The Petri dishes were filled with $100 \mathrm{~mL}$ of culture medium composed of Roswell Park Memorial Institute (RPMI) medium 1640, 10\% fetal calf serum, 5\% horse serum, and 100 units penicillin/streptomycin per milliliter. Rat pheochromocytoma (PC12) cells (ATCC, Wesel, Germany) were then seeded into thus-prepared Petri dishes. The cells were kept in an incubator at $37{ }^{\circ} \mathrm{C}, 90 \%$ humidity, and $5 \% \mathrm{CO}_{2}$, and medium changes were conducted after three to five days of cultivation.

\subsection{Fluorimetric Measurements of Intracellular Calcium Levels}

For fluorometric measurements of $[\mathrm{Ca}]_{\mathrm{i}}$, cover slips adhered with $\mathrm{PC} 12$ cells were incubated in $\mathrm{Na}^{+}$buffer (in mM: $125 \mathrm{NaCl}, 2.5 \mathrm{KCl}, 1 \mathrm{MgCl}_{2}, 2 \mathrm{CaCl}_{2}, 1.3 \mathrm{NaH}_{2} \mathrm{PO}_{4}, 30$ Glucose, and $26 \mathrm{Na}$ HEPES (4-(2-hydroxyethyl)-1-piperazineethanesulfonic acid)) with a final concentration of $10 \mu \mathrm{M} \mathrm{Ca}^{2+}$ fluorescent dye, Flou-3 acetoxymethylester (Flou-3 AM), for $1 \mathrm{~h}$ at $37^{\circ} \mathrm{C}$. Then, the physiological $\mathrm{Na}^{+}$ buffer was removed and replaced with fresh $\mathrm{Na}^{+}$buffer. The cell fluorescence was monitored using an inverted confocal laser scanning microscope (Leica SP5, Wetzlar, Germany) equipped with an argon ion laser for fluorescence excitation (exc $488 \mathrm{~nm}$, em 520-550). Laser settings were identical in all runs and images were taken every second. The beam of the laser scanned the object plane through a Zeiss (Jena, Germany) 20x water immersion objective. We constructed a plastic inlay to reduce the exchangeable volume to $250 \mu \mathrm{L}$, to increase the speed of solution exchange and to minimize the amount of toxins used in the experiment. To increase speed, the compounds were manually pipetted, instead of using pumping or gravity filtration. The experiment took place in an Utermöhl chamber.

10 PC12 cells $(n=10)$ were selected in the cover slips and were analyzed independently using region of interest (ROI)s in the Leica Application Suite Advanced Fluorescence (LAS AF, Wetzlar, Germany) software. The dye intensity represents the calcium concentration inside the cell. Ten individual cells were measured simultaneously in all treatments. The cellular fluorescence emission of the selected PC12 cells was normalized by dividing the fluorescence measured by the initial values ( $t 0)$ and then 
multiplying them by 100. All experiments were replicated using a different cell culture batch obtaining comparable results.

\section{4. $[\mathrm{Ca}]_{i}$ Measurements Using $\mathrm{K}^{+}$Depolarization}

Cover slips with adhered cells were mounted on the microscope using a chamber with a volume capacity of $250 \mu \mathrm{L}$. The fluorescence of the PC12 cells was measured, and cells were subsequently depolarized by submerging $\mathrm{K}^{+}$buffer (in mM: $55 \mathrm{NaCl}, 80 \mathrm{KCl}, 1 \mathrm{MgCl}_{2}, 2 \mathrm{CaCl}_{2}, 1.3 \mathrm{NaH}_{2} \mathrm{PO}_{4}$, 30 Glucose, $26 \mathrm{Na}$ HEPES) through manual pipetting. The effects of the toxin were determined by spiking the $\mathrm{K}^{+}$buffer with GYM A or SPX 1 reaching a final concentration of $0.5 \mu \mathrm{M}$.

\section{5. $[\mathrm{Ca}]_{i}$ Measurements with Application of Acetylcholine}

Cells were stimulated by application of $100 \mu \mathrm{M}$ Acetylcholine-Cl (ACh) (Sigma, Darmstadt, Germany) in $\mathrm{Na}^{+}$buffer (described in Section 4.3). The effects of the toxin were determined by spiking the buffer with either GYM A or SPX 1 resulting in final concentrations of $0.005,0.05$, and $0.5 \mu \mathrm{M}$. In addition, $\mathrm{AChR}$ subtype blockers, atropine and turbocurarine, were utilized in order to investigate the mechanism of action against $\mathrm{AAChR}$ and $\mathrm{mAChR}$, respectively. Both substances were used at a final concentration of $100 \mu \mathrm{M}$.

Author Contributions: Conceptualization, B.K., U.T., J.T. and U.B.; Data curation, J.A.N.; Investigation, J.A.N. and U.B.; Methodology, J.A.N., C.Z. and U.B.; Supervision, U.B.; Visualization, J.A.N.; Writing-original draft, J.A.N. and B.K.; Writing-review \& editing, B.K., U.T., J.T. and U.B. All authors have read and agreed to the published version of the manuscript.

Funding: Financial support was provided by the PACES research program of the Alfred Wegener Institute Helmholtz Centre for Polar and Marine Research. C.Z. was funded by the BMBF (DE) project PROMISE as part of ERA4CS, an ERA-NET marine Biotech initiative with co-funding by the European Union (Grant 031B0561). We acknowledge support by the Open Access Publication Funds of Alfred-Wegener-Institut Helmholtz-Zentrum für Polar- und Meeresforschung.

Conflicts of Interest: The authors declare no conflict of interest.

\section{References}

1. Gobler, C.J. Climate change and harmful algal blooms: Insights and perspective. Harmful Algae 2020, 91. [CrossRef] [PubMed]

2. Guéret, S.M.; Brimble, M.A. Synthetic studies toward the spiroimine unit of the spirolides. Pure Appl. Chem. 2011, 83, 425-433. [CrossRef]

3. Cembella, A.D.; Lewis, N.I.; Quilliam, M.A. The marine dinoflagellate Alexandrium ostenfeldii (Dinophyceae) as the causative organism of spirolide shellfish toxins. Phycologia 2000, 39, 67-74. [CrossRef]

4. Van Wagoner, R.M.; Misner, I.; Tomas, C.R.; Wright, J.L.C. Occurrence of 12-methylgymnodimine in a spirolide-producing dinoflagellate Alexandrium peruvianum and the biogenetic implications. Tetrahedron Lett. 2011, 52, 4243-4246. [CrossRef]

5. Van de Waal, D.B.; Tillmann, U.; Martens, H.; Krock, B.; van Scheppingen, Y.; John, U. Characterization of multiple isolates from an Alexandrium ostenfeldii bloom in The Netherlands. Harmful Algae 2015, 49, 94-104. [CrossRef]

6. Harju, K.; Koskela, H.; Kremp, A.; Suikkanen, S.; de la Iglesia, P.; Miles, C.O.; Krock, B.; Vanninen, P. Identification of gymnodimine $\mathrm{D}$ and presence of gymnodimine variants in the dinoflagellate Alexandrium ostenfeldii from the Baltic Sea. Toxicon 2016, 112, 68-76. [CrossRef]

7. Martens, H.; Tillmann, U.; Harju, K.; Dell'Aversano, C.; Tartaglione, L.; Krock, B. Toxin Variability Estimations of 68 Alexandrium ostenfeldii (Dinophyceae) Strains from The Netherlands Reveal a Novel Abundant Gymnodimine. Microorganisms 2017, 5, 29. [CrossRef]

8. Zurhelle, C.; Nieva, J.; Tillmann, U.; Harder, T.; Krock, B.; Tebben, J. Identification of Novel Gymnodimines and Spirolides from the Marine Dinoflagellate Alexandrium ostenfeldii. Mar. Drugs 2018, 16, 446. [CrossRef] 
9. Seki, T.; Satake, M.; MacKenzie, L.; Kaspar, H.F.; Yasumoto, T. Gymnodimine, a new marine toxin of unprecedented structure isolated from New Zealand oysters and the dinoflagellate, Gymnodinium sp. Tetrahedron Lett. 1995, 36, 7093-7096. [CrossRef]

10. Van Wagoner, R.M.; Satake, M.; Wright, J.L.C. Polyketide biosynthesis in dinoflagellate: What makes it different? Nat. Prod. Rep. 2014, 31, 1101. [CrossRef]

11. Otero, P.; Alfonso, A.; Rodríguez, P.; Rubiolo, J.A.; Cifuentes, J.M.; Bermúdez, R.; Vieytes, M.R.; Botana, L.M. Pharmacokinetic and toxicological data of spirolides after oral and intraperitoneal administration. Food Chem. Toxicol. 2012, 50, 232-237. [CrossRef] [PubMed]

12. Gill, S.; Murphy, M.; Clausen, J.; Richard, D.; Quilliam, M.; MacKinnon, S.; LaBlanc, P.; Mueller, R.; Pulido, O. Neural Injury Biomarkers of Novel Shellfish Toxins, Spirolides: A Pilot Study Using Immunochemical and Transcriptional Analysis. Neurotoxicology 2003, 24, 593-604. [CrossRef]

13. Munday, R.; Towers, N.R.; Mackenzie, L.; Beuzenberg, V.; Hollan, P.T.; Miles, C.O. Acute toxicity of gymnodimine to mice. Toxicon 2004, 44, 173-178. [CrossRef] [PubMed]

14. Kharrat, R.; Servent, D.; Girard, E.; Ouanounou, G.; Amar, M.; Marrouchi, R.; Benoit, E.; Molgo, J. The marine phycotoxin gymnodimin targets muscular and neuronal nicotinic acetylcholine receptor subtypes with high affinity. J. Neurochem. 2008, 107, 952-963. [CrossRef]

15. Aráoz, R.; Ouanounou, G.; Iorga, B.I.; Goudet, A.; Alili, D.; Amar, M.; Benoit, E.; Molgó, J.; Servent, D. The Neurotoxic Effect of 13,19-Didesmethyl and 13-Desmethyl Spirolide C Phycotoxins Is Mainly Mediated by Nicotinic Rather Than Muscarinic Acetylcholine Receptors. Toxicol. Sci. 2015, 147, 156-157. [CrossRef]

16. Bourne, Y.; Radić, Z.; Aráoz, R.; Talley, T.T.; Benoit, E.; Servent, D.; Taylor, P.; Molgó, J.; Marchot, P. Structural determinants in phycotoxins an AChBP conferring high affinity binding and nicotinic AChR antagonism. Proc. Natl. Acad. Sci. USA 2010, 107, 6076-6081. [CrossRef]

17. Hauser, T.A.; Hepler, C.D.; Kombo, D.C.; Grinevich, V.P.; Kiser, M.N.; Hooker, D.N.; Zhang, J.; Mountfort, D.; Selwood, A.; Akireddy, S.R.; et al. Comparison of acetylcholine receptor interactions of the marine toxins, 13-desmethylspirolide C and gymnodimine. Neuropharmacology 2012, 62, 2239-2250. [CrossRef]

18. Wandscheer, C.B.; Vilariño, N.; Espiña, B.; Louzao, M.C.; Botana, L.M. Human muscarinic acetylholine receptors are a target of the marine toxin 13-desmethyl C spirolide. Chem. Res. Toxicol. 2010, 11, 1753-1761. [CrossRef]

19. Friis, S.; Mathes, C.; Sunesen, M.; Bowlby, M.R.; Dunlop, J. Characterization of compounds on nicotinic acetylcholine receptor alpha7 channels using high throughput electrophysiology. J. Neurosci. Methods 2009, 177, 142-148. [CrossRef]

20. Shafer, T.J.; Atchison, W.D. Transmitter, ion channel and receptor properties of pheochromocytoma (PC12) cells: A model for neurotoxicological studies. Neurotoxicology 1991, 12, 473-492.

21. Seta, K.; Kim, H.W.; Ferguson, T.; Kim, R.; Pathrose, P.; Yuan, Y.; Lu, G.; Spicer, Z.; Millhorn, D.E. Genomic and Physiological Analysis of Oxygen Sensitivity and Hypoxia Tolerance in PC12 Cells. Ann. N. Y. Acad. Sci. 2002, 971, 379-388. [CrossRef] [PubMed]

22. Catterall, W.A. Structure and function of voltage-gated ion channels. Annu. Rev. Biochem. 1995, 64, 493-531. [CrossRef] [PubMed]

23. Gotti, C.; Zoli, M.; Clementi, F. Brain nicotinic acetylcholine receptors: Native subtypes and their relevance. Trends Pharmacol Sci. 2006, 27, 482-491. [CrossRef] [PubMed]

24. Hurst, R.; Rollema, H.; Bertrand, D. Nicotinic acetylcholine receptors: From basic science to therapeutics. Pharmacol. Therapeut. 2013, 1, 22-54. [CrossRef]

25. Brann, M.R.; Ellis, J.; Jørgensen, H.; Hill-Eubanks, D.; Jones, S.V.P. Chapter 12: Muscarinic acetylcholine receptor subtypes: Localization and structure/function. Prog. Brain Res. 1993, 98, 121-127. [CrossRef]

26. Takahashi, T.; Yamashita, H.; Nakamura, S.; Ishiguro, H.; Nagatsu, T.; Kawakami, H. Effects of nerve growth factor and nicotine on the expression of nicotinic acetylcholine receptor subunits in PC12 cells. J. Neurosci. Sci. 1999, 35, 175-181. [CrossRef]

27. Michel, A.D.; Stefanich, E.; Whiting, R.L. PC12 phaeochromocytoma cells contain an atypical muscarinic receptor binding site. Br. J. Pharmacol. 1989, 97, 914-920. [CrossRef]

28. Berridge, M.J.; Lipp, P.; Bootman, M.D. The versatility of calcium signaling. Nat. Rev. Mol. Cell Biol. 2000, 1, 11-21. [CrossRef] 
29. Bickmeyer, U.; Grube, A.; Klings, K.W.; Pawlick, J.R.; Köck, M. Siphonodictyal B1 from a Marine Spong Increases Intracellular Calcium Levels Comparable to Ca2+-ATPase (SERCA) Inhibitor Thapsigargin. Mar. Biotechnol. 2010, 12, 267-272. [CrossRef]

30. Spalding, T.A.; Burstein, E.S. Constitutive activity of muscarinic acetylcholine receptors. J. Recept. Sig. Transd. 2006, 26, 61-65. [CrossRef]

31. Zwart, R.; Vijverberg, H.P.M. Potentiation and inhibition of neuronal nicotinic receptors by atropine: Competitive and non-competitive effects. Mol. Pharmacol. 1997, 52, 886-895. [CrossRef] [PubMed]

32. Parker, J.C.; Sarkar, D.; Quick, M.W.; Lester, R.A.J. Interactions of atropine with heterogously expressed and native $\alpha 3$ subunit-containing nicotine acetylcholine receptors. Br. J. Pharmacol. 2003, 138, 801-810. [CrossRef] [PubMed]

33. Albuquerque, E.X.; Pereira, E.F.R.; Alkondon, M.; Rogers, S.W. Mammalian Nicotinic Acetylcholine Receptors: From Structure to Function. Physiol. Rev. 2008, 89, 73-120. [CrossRef] [PubMed]

34. Eglen, R.M. Muscarinic Receptor Subtype Pharmacology and Physiology. Prog. Med. Chem. 2005, 43, $105-136$. [CrossRef]

Publisher's Note: MDPI stays neutral with regard to jurisdictional claims in published maps and institutional affiliations.

(C) 2020 by the authors. Licensee MDPI, Basel, Switzerland. This article is an open access article distributed under the terms and conditions of the Creative Commons Attribution (CC BY) license (http://creativecommons.org/licenses/by/4.0/). 